\title{
Peranan Dewan Pengawas Syariah terhadap Praktik Kepatuhan Syariah dalam Perbankan Syariah di Indonesia
}

\author{
Bagya Agung Prabowo dan Jasri Bin Jamal \\ Faculty of Law Universiti Kebangsaan Malaysia and Faculty of Law Universitas \\ Islam Indonesia Yogyakarta, Faculty of Law Universiti Kebangsaan Malaysia \\ Tamansiswa Street No. 158 Yogyakarta; The National University of Malaysia, 43600 \\ UKM Bangi Selangor Darul Ehsan Malaysia \\ bagya.agung@uii.ac.id; jasri@ukm.edu.my
}

Naskah diterima: 22/11/2016; revisi: 29/11/2016; disetujui: 20/12/2016

\begin{abstract}
This research is to analyze the role of DPS (Dewan Pengawas Syariah or Sharia Supervisory Board) towards the practice of sharia obedience with the perspective of customer protection in sharia banking in Indonesia. This research adopted the analysis method based upon the doctrinal content by applying four types of legal approach including: (i) history; (ii) Figh/philosophy; (iii) comparison and (iv) analysis and critical. In addition, the approach alignment is also needed for the legislative alignment with Islamic philosophy and customer protection philosophy. The result of the research concluded that any violation in sharia obedience neglected by DPS will negatively impact the image and credibility of sharia banking to public; thus, it can bring an impact on the public trust. For this reason, the roles of DPS in sharia banking needs to be optimized, for instance related to the qualification of DPS appointment must be tighter and the support to its roles must be realized in sharia banking. DSN MUI as an institution issuing the fatwa (binding ruling) can make the coordination and equalize the perception with the DPS posted in sharia banks in Indonesia in supervising the operation of sharia bank to make it really playing a role and ready to run its task as the DPS.
\end{abstract}

Keywords: Roles; supervisory; sharia obedience

Abstrak

Penelitian ini mengkaji tentang peranan Dewan Pengawas Syariah (DPS) terhadap praktik kepatuhan syariah yang berperspektif perlindungan konsumen dalam perbankan syariah di Indonesia. Penelitian ini mengadopsi metode analisis berdasarkan konten doktrinal, dengan menerapkan empat jenis pendekatan hukum, yaitu: (i) sejarah / historis; (ii) Fikih / filsafat; (iii) perbandingan; dan (iv) analitis dan kritis. Selain itu, pendekatan diselaraskan juga diperlukan untuk penyelarasan legislatif dengan filsafat Islam dan filsafat perlindungan konsumen. Hasil penelitian menyimpulkan bahwa pelanggaran kepatuhan syariah yang dibiarkan oleh DPS akan merusak citra dan kredibilitas perbankan syariah di mata publik, sehingga dapat mengurangi kepercayaan masyarakat terhadap perbankan syariah tersebut. Untuk alasan ini peran DPS pada perbankan syariah benar-benar perlu dioptimalkan, di antaranya kualifikasi pengangkatan DPS harus diperketat, dan dukungan atas peranannya harus diwujudkan dalam perbankan syariah. DSN MUI sebagai lembaga yang mengeluarkan fatwa dapat berkoordinasi dan menyamakan persepsi dengan DPS yang ditempatkan di bank-bank syariah di Indonesia dalam mengawasi operasional perbankan syariah agar mereka benar-benar berperan dan siap menjalankan tugas sebagai DPS.

Kata-kata Kunci: Peran; pengawas; kepatuhan syariah 


\section{Pendahuluan}

Islam adalah suatu sistem hidup yang lengkap dan universal untuk menyusun dan memberikan arahan yang dinamis dan mudah untuk semua aspek kehidupan, termasuk bisnis dan transaksi keuangan. ${ }^{1}$ Satu fenomena yang muncul dalam tiga dekade yang lalu ialah pertumbuhan pesat industri perbankan syariah. Industri perbankan syariah sebenarnya dijalankan berdasarkan prinsip dan sistem syariah. Oleh karena itu, kesesuaian operasional dan praktik bank syariah dengan syariah merupakan perangkat mendasar dalam perbankan syariah. ${ }^{2}$ Bank syariah memiliki tiga fungsi utama yaitu mengumpulkan dana dari masyarakat dalam bentuk deposito dan investasi, menyalurkan dana kepada masyarakat yang membutuhkan dana dari bank dan menyediakan layanan dalam bentuk layanan perbankan syariah. ${ }^{3}$ Bank syariah dalam menjalankan fungsi utamanya memiliki risiko, terutama dalam menyalurkan dana kepada masyarakat. Salah satunya adalah risiko pembiayaan, yaitu risiko yang disebabkan oleh kegagalan pihak berlawanan untuk memenuhi kewajibannya, risiko yang terkait produk pembiayaan dan pendanaan perusahaan terkait. ${ }^{4}$

Penduduk Indonesia yang mayoritas beragama Islam merupakan captive market yang menguntungkan bagi pengembangan perbankan syariah. Captive market memiliki arti bahwa mayoritas penduduk tersebut memiliki sentimen psikologi untuk lebih mengutamakan penggunaan pelayanan bank syariah karena jaminan keamanan (halal) yang ditawarkan, sudah tentu dengan catatan bahwa pelayanan dan kemudahan yang dimiliki oleh bank syariah juga tidak mengecewakan. ${ }^{5}$ Bentuk kegiatan operasional bank syariah terbagi kepada tiga bagian dalam bentuk produkproduk yang dikeluarkan oleh bank syariah, masing-masing adalah produk menghimpun dana masyarakat, produk penyaluran dana masyarakat dan produk yang berkaitan dengan pelayanan perbankan yang diberikan kepada nasabah. ${ }^{6}$ Al-

\footnotetext{
${ }^{1}$ Muhammad Syafi'i Antonio, Bank Syariah: dari Teori ke Praktik, Gema Insani Press, Jakarta, 2010, hlm. 21.

${ }^{2}$ Warkum Sumitro, Asas-Asas Perbankan Islam dan Lembaga-Lembaga Terkait, RajaGrafindo Persada, Jakarta, 2004, hlm. 18.

${ }^{3}$ Ismail, Perbankan Syariah, Cetakan Kedua, Kencana Prenada Media Group, Jakarta, 2013, hlm. 23.

${ }_{4}^{4}$ Adiwarman A. Karim, Bank Islam: Analisis Fiqib dan Kuangan, PT. RajaGrafindo Persada, Jakarta, 2011, hlm. 27.

${ }^{5}$ Muhammad, Bank Syariah Analisis Kekuatan, Peluang, Kelemahan dan Ancaman, Cetakan Pertama, Ekonosia, Yogyakarta, 2006, hlm. 14.

${ }^{6}$ Muhammad Syafi'i Antonio, Bank Syariah Wacana Ulama dan Cendekiawan, Cetakan Pertama, Tazkia Institute, Jakarta, 1999, hlm. 34.
} 
Quran dan Sunnah hanya menyediakan prinsip dasar filosofis dan menegaskan larangan yang harus dijauhi. Jadi apa yang perlu dilakukan adalah untuk mengidentifikasi hal-hal yang dilarang oleh Islam. Selain itu, segala sesuatu adalah diperbolehkan dan kita dapat melakukan inovasi dan kreativitas sebanyak mungkin. ${ }^{7}$ Semakin kompleknya permasalahan yang dihadapi Lembaga Keuangan Syariah (LKS) saat ini menuntut semakin sigapnya DSN-MUI terhadap innovasiinnovasi produk yang dibutuhkan masyarakat. Hal ini untuk memajukan dan meningkatkan pertumbuhan LKS di tanah air. ${ }^{8}$ Perbankan syariah dalam aktivitas operasionalnya harus menjalankan fungsinya dengan baik, sesuai dengan ketentuan perbankan yang berlaku dan sesuai pula dengan prinsip syariah. Untuk menjamin terlaksananya prinsip syariah dalam aktivitas perbankan syariah terdapat salah satu pihak terafiliasi yaitu Dewan Pengawas Syariah sebagai pihak yang memberikan jasanya kepada bank syariah atau Unit Usaha Syariah (UUS). Dewan inilah sebagai pihak yang bertanggung jawab atas informasi tentang kepatuhan pengelola bank akan prinsip syariah. ${ }^{9}$ Sebagaimana yang diamanatkan dalam Undang-Undang No. 40 Tahun 2007 tentang Perseroan Terbatas dan Undang-Undang No. 21 Tahun 2008 tentang Perbankan Syariah yang menyebutkan bahwa bank syariah harus memiliki 3 orang Dewan Pengawas Syariah (DPS). Peranan DPS sangat strategis dalam praktik kepatuhan syariah pada institusi perbankan syariah di Indonesia.

Pengawasan secara etimology lughawi berarti rigabah makna lughawi penjagaan, penyelenggaraan dan pemantauan, sebagaimana firman Allah dalam surah An-Nisa ayat 1, Sesungguhnya Allah senatiasa mengawasi kalian. Pengawasan dalam pengertian istilah syariah bermakna pemantauan (isyraf), pemeriksaan (muraja'ah) dan investigasi (fahsh) bertujuan untuk menjaga manfaat (mura'at maslahah) dan menghindari kehancuran (idra' mafsadah).10 Istilah pengawasan menurut Kamus Besar Bahasa Indonesia (KBBI) berasal dari perkataan awas yang

\footnotetext{
${ }^{7}$ Ibid., hlm. 36.

${ }^{8}$ Imam Abdul Hadi, "Kedudukan dan Wewenang Lembaga Fatwa (DSN MUI) pada Bank Syariah", Jurnal Economic, Vol. 1, No. 2, 2011, hlm. 2.

9 Suryani, "Industri Perbankan Syariah dalam Cerminan Aspek Sharia Governance", Jurnal Ecomomica, Vol.V, Edisi 1, 2014, hlm. 104.

${ }_{10}$ Muhammad Ridwan, Konstruksi Bank Syariah Indonesia, Cet. Pertama, Pustaka SM, Yogyakarta, 2007, hlm. 27.
} 
bermaksud memberi perhatian dilihat dengan baik, dalam arti melihat sesuatu dengan teliti dan menyeluruh, kegiatan yang tidak lebih daripada memberikan laporan berdasarkan realitas sesungguhnya apa yang diawasi. ${ }^{11}$ Sedangkan dalam bahasa Inggris disebut controlling diterjemahkan dengan istilah pengawasan dan pengendalian, sehingga istilah controlling lebih luas artinya daripada pengawasan, tetapi di kalangan pakar-pakar telah disamakan pengertian controlling ini dengan pengawasan, jadi pengawasan termasuk pengendalian. Pengendalian berasal dari kendali, supaya membayangkan pengendalian langsung, kegiatan perbaikan yang salah dan meluruskan arah yang benar. ${ }^{12}$

Fungsi dan peranan DPS pada bank syariah, memiliki hubungan yang kuat dengan pengurusan risiko perbankan syariah, yakni risiko reputasi yang selanjutnya memberi kesan pada risiko lain, seperti risiko likuiditas. Kegiatan perbankan syariah harus menerapkan prinsip-prinsip syariah dalam transaksi ekonomi dan selain dari hal-hal yang dilarang oleh Islam seperti riba, judi, spekulasi dan lain-lain. ${ }^{13}$ Setiap kontrak dalam kegiatan bisnis, terutama kontrakkontrak pengumpulan dan distribusi dana pada saat ini telah diatur dalam PBI No. 7/46/PBI/2005 tentang Akad Pengumpulan dan Pembayaran untuk Menjalankan Usaha Bank Berdasarkan Prinsip Syariah. ${ }^{14}$

\section{Rumusan Masalah}

Berdasarkan uraian di atas, permasalahan yang dikaji dalam penelitian ini adalah: bagaimanakah peranan Dewan Pengawas Syariah (DPS) terhadap praktik kepatuhan syariah yang berperspektif perlindungan konsumen dalam perbankan syariah di Indonesia?

\section{Tujuan Penelitian}

Adapun penelitian ini bertujuan untuk mengetahui dan menganalisis peranan Dewan Pengawas Syariah (DPS) terhadap praktik kepatuhan syariah yang berperspektif perlindungan konsumen dalam perbankan syariah di Indonesia.

${ }^{11}$ Sujamto, Beberapa Pengertian di Bidang Pengawasan, Cetakan Pertama, Ghalia Indonesia, Jakarta, 1986, hlm. 9.

12 Victor M. Situmorang, Aspek. Hukum Pengawasan Melekat, Rineka Cipta, Jakarta, 1994, hlm. 21.

13 Adrian Sutedi, Pasar Modal Syariab: Sarana Investasi Kenangan Berdasarkan Prinsip Syariah, Sinar Grafika, Jakarta, 2011, hlm. 31.

${ }^{14}$ Gemala Dewi, Hukum Perikatan Islam di Indonesia, Cetakan Ketiga, Kencana Prenada Group, Jakarta, 2007, hlm. 28. 


\section{Metode Penelitian}

Penelitian ini merupakan penelitian hukum normatif, yaitu penelitian yang dilakukan terhadap asas-asas hukum, kaedah-kaedah hukum dalam arti nilai (norm), peraturan hukum konkrit dan sistem hukum ${ }^{15}$ yang berhubungan dengan materi yang diteliti. Pendekatan penelitian yang digunakan adalah: a. Pendekatan perundang-undangan (statute approach), yaitu dilakukan dengan menelaah undangundang dan regulasi yang berkaitan dengan masalah yang dibahas; ${ }^{16} \mathrm{~b}$. Pendekatan konseptual (conceptual approach), dilakukan dengan mengkaji pandangan para ahli yang berkenaan dengan masalah yang dibahas. Pendekatan ini dilakukan manakala aturan hukum tidak ada atau belum ada ${ }^{17}$ sehingga pandangan para ahli menjadi salah satu dasar dalam menguatkan pandangan peneliti; c. Pendekatan perbandingan (comparative approach), dilakukan dengan mengadakan perbandingan hukum. Perbandingan hukum sangat bermanfaat karena dengan membandingkan dapat terungkap latar belakang adanya ketentuan hukum tersebut sehingga dapat menjadi rekomendasi bagi penyusunan peraturan perundang-undangan yang sesuai dengan pembahasan peneliti. ${ }^{18}$ Malaysia dipilih sebagai negara pembanding karena memiliki perundang-undangan tentang perbankan syariah lebih lama dan lebih lengkap.

\section{Hasil Penelitian dan Pembahasan}

Pelanggaran terhadap kepatuhan syariah yang dibiarkan oleh DPS atau luput dari pengawasan DPS, jelas akan merusak citra dan kredibilitas bank syariah di mata masyarakat, sehingga dapat menurunkan kepercayaan masyarakat pada bank syariah. Bank syariah sebagai pengumpul dan pendistributor dana publik harus memiliki tingkat kepercayaan yang tinggi dalam masyarakat dan dalam dunia usaha. Reputasi ini bukanlah satu hal yang mudah, tetapi harus diusahakan dengan penuh disiplin dan bersungguh-sungguh. Apabila amanah telah dicapai, upaya untuk mempertahankan status ini juga bukan hal yang mudah. Satu hal kecil yang dapat menggugat keyakinan dan, selanjutnya, akan berubah menjadi bencana. ${ }^{19}$

\footnotetext{
15 Sudikno Mertokusumo, Penemuan Hukum, Liberty, Yogyakarta, 2004, hlm. 29.

${ }^{16}$ Peter Mahmud Marzuki, Penelitian Hukum, Prenada Group, Jakarta, 2014, hlm. 136.

${ }^{17}$ Ibid.

${ }^{18}$ Ibid., hlm. 173.

${ }^{19}$ M. Umer Chapra dan Tariqullah Khan, Regulasi dan Pengawasan Bank Syariah, Bumi Aksara, Jakarta, 2008,
} hlm. 49 . 
Untuk itulah peran DPS pada bank syariah harus benar-benar dioptimalkan, kualifikasi menjadi DPS harus diperketat, dan formalisasi perannya harus diwujudkan pada bank syariah tersebut. Menurut Undang-Undang Nomor 40 Tahun 2007 Pasal 109, menyebutkan: 1. Perusahaan yang menjalankan bisnis yang berbasis prinsip-prinsip syariah selain memiliki Dewan Komisaris memiliki Dewan Pengawasan Syariah; 2. Dewan Pengawas Syariah sebagaimana dimaksud pada ayat (1) terdiri atas seorang yang ahli syariah atau lebih yang ditunjuk oleh RUPS atas rekomendasi Majelis Ulama Indonesia (MUI); 3. Dewan Pengawas Syariah sebagaimana dimaksud pada ayat (1) adalah petunjuk dan nasihat kepada Direksi dan mengawasi kegiatan-kegiatan Perusahaan untuk mematuhi prinsip-prinsip Islam.

Berdasarkan undang-undang ini, maka setiap badan hukum atau perusahaan yang beroperasional berdasarkan prinsip syariah hendaklah memiliki DPS. Oleh karena itu, Undang-Undang No. 21 Tahun 2008 Pasal 32 menyebutkan: 1. Dewan Pengawas Syariah hendaklah didirikan di Bank Syariah dan Bank Umum Konvensional yang memiliki Usaha Unit Syariah (UUS); 2. Dewan Pengawas Syariah sebagaimana dimaksud pada ayat (1) ditetapkan oleh Rapat Umum Pemegang Saham atas rekomendasi Majelis Ulama Indonesia; 3. Dewan Pengawas Syariah sebagaimana dimaksud pada ayat (1) bertugas memberikan nasihat dan saran kepada direksi serta mengawasi kegiatan-kegiatan bank agar mematuhi prinsip-prinsip Syariah; 4. Ketentuan lebih lanjut mengenai berdirinya Dewan Pengawasan Syariah sebagaimana dimaksud pada ayat (1) diatur oleh Bank Indonesia. Berdasarkan Undang-Undang Perbankan Syariah Pasal 32, maka perbankan syariah harus mendirikan DPS seperti yang dimandatkan oleh UndangUndang No. 21 Tahun 2008 tentang Perbankan Syariah.

\section{Tanggung Jawab Dewan Pengawas Syariah (DPS)}

Dewan Pengawas Syariah (DPS) dalam perbankan syariah memiliki peranan yang penting dan strategis dalam pengawasan syariah pada perbankan syariah. DPS adalah bertanggungjawab untuk memastikan semua produk dan prosedur bank syariah sesuai prinsip-prinsip syariah. Karena peranan yang penting dalam DPS, kedua undang-undang di Indonesia termasuk kebutuhan DPS dalam 
perusahaan berdasarkan syariah dan institusi perbankan syariah yaitu UndangUndang No. 40 Tahun 2007 tentang Perseroan Terbatas dan Undang-Undang No. 21 Tahun 2008 tentang Perbankan Syariah. Oleh karena itu, secara yuridis Dewan Pengawas Syariah (DPS) pada institusi perbankan mempunyai kedudukan yang sangat kuat, karena kehadirannya adalah sangat penting dan strategis.

Pengoptimalan peranan DPS adalah sangat penting untuk memastikan setiap transaksi sesuai prinsip-prinsip syariah yang merujuk kepada al-Qur'an dan Sunnah, dalam hal ini, fatwa Dewan Syariah Nasional Majelis Ulama Indonesia. Pedoman dasar DSN MUI Bab IV ayat (2) menyatakan bahwa DSN MUI mengeluarkan fatwa yang mengikat DPS di setiap institusi keuangan syariah dan menjadi dasar bagi para pihak untuk mengambil tindakan hukum yang berkaitan, yaitu berdasarkan fatwa yang dikeluarkan oleh DSN MUI dirujuk oleh DPS. ${ }^{20}$ DSN merupakan satu-satunya badan yang mempunyai kewenangan mengeluarkan fatwa Syariah terhadap jenisjenis kegiatan, produk, dan jasa keuangan syariah, serta mengawasi penerapan fatwa dimaksud oleh lembaga-lembaga keuangan di Indonesia. ${ }^{21}$ Di samping itu, peran DPS dan DSN bukan hanya mengawasi operasional lembaga keuangan syariah saja, tetapi memiliki peran yang lebih besar lagi yaitu turut mendorong tumbuh kembangnya ekonomi dan keuangan syariah di Indonesia. ${ }^{22}$

Keberadaan DPS yang disebut dalam Pasal 32 Undang-Undang No. 21 Tahun 2008 pada dasarnya DPS hendaklah didirikan di bank-bank syariah dan bank konvensional yang memiliki unit-unit usaha syariah, mereka dilantik oleh Rapat Umum pemegang saham atas rekomendasi Majelis Ulama Indonesia. DPS ditugaskan untuk memberikan nasehat kepada para direktur dan mengawasi kegiatan-kegiatan bank untuk disesuaikan dengan prinsip-prinsip syariah. ${ }^{23}$

Undang-Undang No. 40 Tahun 2007 Pasal 109 menyebutkan: 1. Perusahaan yang menjalankan usaha yang berdasarkan prinsip-prinsip syariah selain memiliki

\footnotetext{
${ }^{20}$ Hirsanuddin, Hukum Perbankan Syariah di Indonesia (Pembiayaan Bisnis dengan Prinsip Kemitraan), Cetakan Pertama, Genta Press, Yogyakarta, 2008, hlm. 42.

${ }^{21}$ Minarni, "Konsep Pengawasan, Kerangka Audit Syariah dan tata Kelola Lembaga Keuangan Syariah", Jurnal Ekonomi Islam La_Riba, Vol. VII, No. 1, Juli 2013, hlm. 32.

${ }^{22}$ Fitra Nelli, "Problematika Kiprah Dewan Pengawas Syariah (DPS) di Perbankan Syariah, Jurnal AlMasharif, Vol. III, No. 1, Januari - Juni 2015, hlm. 91

23 Abdul Ghofur Anshori, Hukum Perbankan Syariah (UU No. 21 Tabun 2008), Cetakan Pertama, Refika Aditama, Bandung, 2009, hlm. 48.
} 
Dewan Komisaris memiliki Dewan Pengawasan Syariah; 2. Dewan Pengawas Syariah sebagaimana dimaksud pada ayat (1) hendaklah terdiri daripada seorang pakar syariah atau lebih yang dilantik oleh ditetapkan oleh Rapat Umum Pemegang Saham atas rekomendasi Majelis Ulama Indonesia; 3. Dewan Pengawas Syariah sebagaimana dimaksud pada ayat (1) akan memberikan petunjuk dan nasihat kepada Direktur dan mengawasi kegiatan-kegiatan perusahaan untuk mematuhi prinsip-prinsip Islam. Berdasarkan undang-undang ini, perusahaan yang berbadan hukum Perseroan Terbatas hendaklah memiliki Dewan Pengawasan Syariah. Oleh karena itu, Undang-Undang No. 21 Tahun 2008 Pasal 32 menyebutkan: 1. Dewan Pengawas Syariah hendaklah didirikan di bank syariah dan bank konvensional yang memiliki Unit Usaha Syariah (UUS); 2. Dewan Pengawas Syariah sebagaimana dimaksud pada ayat (1) ditetapkan oleh Rapat Umum Pemegang Saham atas rekomendasi Majelis Ulama Indonesia; 3. Dewan Pengawas Syariah sebagaimana dimaksud pada ayat (1) akan memberikan petunjuk dan nasihat kepada para Direktur dan mengawasi kegiatan-kegiatan bank mematuhi prinsip-prinsip syariah; 4 . Ketentuan lebih lanjut mengenai pendirian Dewan Pengawasan Syariah sebagaimana dimaksud pada ayat (1) diatur oleh Bank Indonesia.

Di bawah peraturan ini adalah jelas bahwa kedudukan DPS kuat dan sebagian besar menentukan perkembangan bank-bank syariah dan unit-unit usaha syariah.

DPS berdasarkan AAOIFI (Accounting and Auditing Organization of Islamic Financial Institutions) telah menyediakan standar untuk DPS, komposisi, dan aspekaspek yang berkaitan seperti peraturan, laporan dan sebagainya. Menurut standar ini, lembaga syariah harus menjadi lembaga bebas yang terdiri dari para ulama yang berkaitan dengan ilmu pengetahuan dan hukum Islam. DPS juga dapat terdiri dari ahli-ahli lain dalam bidang institusi keuangan syariah dengan pengetahuan sains undang-undang Islam yang berkaitan dengan transaksi komersial. DPS diamanahkan dengan tugas mengarahkan, meneliti dan mengawasi kegiatan institusi keuangan syariah untuk memastikan bahwa ia mematuhi peraturan dan prinsip-prinsip syariah. ${ }^{24}$

${ }^{24}$ Muhammad Ayub, Understanding Islamic Finance, diterjemahkan oleh Aditya Wisnu Pribadi, PT Gramedia Pustaka Utama, Jakarta, 2009, hlm. 52. 


\section{Peranan Dewan Pengawas Syariah dalam Industri Perbankan Syariah}

Dalam industri perbankan syariah pelayanan yang diberikan oleh bank kepada nasabah mana pada umumnya tidak bertentangan dengan prinsip syariah. Oleh karena pelayanan yang diberi bukan bertujuan sekedar untuk mendapat keuntungan seperti bank konvensional maka bank akan mengaplikasikan beberapa kontrak syariah yang sesuai. ${ }^{25}$ Dewan Pengawas Syariah memiliki peranan yang amat penting dalam perbankan syariah selaras dengan kontrak syariah yaitu: 1 . Membuat pedoman persetujuan produk dan opersional perbankan syariah berdasarkan ketentuan yang telah disusun oleh Dewan Syariah Nasional (DSN); 2. Membuat laporan secara rutin pada setiap tahun tentang bank syariah yang berada dalam pengawasannya bahwa bank yang diawasinya telah berjalan sesuai dengan ketentuan syariah. Dalam laporan tahunan (annual report) institusi syariah, maka laporan dari DPS mesti dibuat dengan jelas; 3. Dewan Pengawas Syariah hendaklah membuat suatu laporan kepada pembangunan dan aplikasi sistem keuangan syariah di institusi keuangan syariah khususnya bank-bank syariah yang berada dalam pengawasan, sekurang-kurangnya enam bulan sekali. Laporan telah diberikan kepada Bank Indonesia terletak di ibukota propinsi dan atau Bank Indonesia di ibu kota negara Indonesia, Jakarta; 4. Dewan Pengawas Syariah juga bertanggungjawab untuk mengkaji dan membuat usulan jika terdapat produk baru inovasi dari bank yang diawasinya. Majelis ini menjalankan penilaian awal sebelum produk yang baru dari bank syariah yang diussulkan itu sekali lagi diperiksa dan difatwakan oleh DSN; 5. Membantu sosialisasi syariah institusi keuangan perbankan/kepada masyarakat; 6. Memberi input untuk pembangunan dan kemajuan institusi keuangan syariah.

Sebagai perbandingan, tugas lembaga pengawasan syariah di Malaysia dikendalikan oleh suatu badan yang dinamakan Majelis Penasihat Syariah (MPS). Majelis Penasihat Syariah hanya terdapat di banak sentral Malaysia, yaitu Majelis Penasihat Syariah Bank Negara Malaysia (MPS BNM) yang merupakan suatu badan yang didirikan selaras dengan pendirian perusahaan keuangan yang

${ }^{25}$ Hailani Muji Tahir, Sanep Ahmad, Aplikasi Fiqh Muamalat dalam Sistem Keuangan syariah, Pusat Penerbitan Universiti (UPENA), Shah Alam, 2009, hlm. 43. 
berdasarkan Islam. Anggotanya terdiri dari pakar-pakar ekonomi yang juga turut memiliki kepakaran di dalam bidang syariah. MPS BNM memiliki kedudukan lebih tinggi berbanding dengan jawatan kuasa syariah bank-bank perdagangan. Jika terdapat perbedaan keputusan antara Majelis Penasihat Syariah Bank Negara dengan Jawatan kuasa Syariah bank lain, maka keputusan Majelis Penasihat Syariah Bank Negara adalah yang digunakan. Sejak beberapa dekade terakhir, MPS telah menjalankan fungsi sebagai badan rujukan dan berwenang menyelesaikan isu kepatuhan syariah dalam perbankan dan keuangan syariah di Malaysia. Majelis Penasihat Syariah Bank Negara ini pada umumnya berfungsi dalam memberi fatwa berkaitan dengan perbankan dan asuransi Islam, membuat pengawasan, kepatuhan syariah dan pengauditan. Ini adalah karena perkembangan terkini industri keuangan syariah terlihat banyak inovasi produk keuangan syariah yang semakin kompleks dan bermacam-macam. Selain itu MPS BNM juga perlu menjalankan kerjasama dan komunikasi di kalangan ahli-ahli syariah dan praktisi industri melanjutkan penggabungan pengetahuan, pengalaman dan informasi menyatu secara terus-menerus, sehingga dapat meningkatkan efektivitas proses pengawasan untuk menjamin kepatuhan syariah.

Peranan MPS BNM bagi perbankan syariah di Malaysia secara khusus adalah sebagi berikut: 1. Mencantumkan daftar sekuritas patuh syariah. Daftar patuh syariah dimaksud, dikeluarkan oleh MPS sebanyak 2 kali setahun yaitu pada bulan Mei dan September setiap tahun. Daftar ini sangat penting dalam membantu para investor Islam dalam mengidentifikasi sekuritas yang sesuai dengan prinsip Syariah dan seterusnya meningkatkan keyakinan mereka tanpa keraguan dalam membuat investasi; 2. Memberi nasihat tentang produk-produk pasar modal. Di antara tugasnya antara lain mengambil dua pendekatan, yaitu yang pertama mereka akan mengkaji keabsahan instrumen konvensional yang dilakukan oleh pasar modal berdasarkan perspektif syariah. Ulasan dimaksud, terkonsentrasi pada struktur, mekanisme dan penggunaan instrumen tersebut apakah ada prinsip yang bertentangan dengan prinsip syariah atau tidak. Selanjutnya pendekatan kedua, menyusun dan membentuk instrumen baru yang berlandaskan syariah; 3 . Memberi nasihat dalam penanganan asuransi. Tugas tersebut dimaksudkan agar dana asuransi diinvestasikan dalam instrumen yang diharuskan syariah saja. Jadi, 
jika terjadi pembayaran kepada peserta yang membutuhkan bantuan, dana tersebut telah bersumber dari aktivitas yang halal dan bukan bersumber dari investasi yang mengandung unsur riba; 4 . Memberi nasihat kepada Direktur dan lembaga keuangan. Contoh nasihat tersebut antara lain dan utama ialah memberi nasihat kepada lembaga-lembaga keuangan seperti bank-bank komersial yang ingin mengeluarkan sesuatu produk perbankan yang terbaru, untuk memastikan produk tersebut memenuhi persyaratan syariah; 5. Verifikasi manual patuh syariah. Dalam menyediakan satu sumber referensi yang tersusun untuk menentukan apakah suatu produk perbankan telah melewati syarat patuh syariah atau tidak, MPS akan mengkonfirmasi suatu petunjuk yang telah dihasilkan melalui diskusi antara anggota-anggota Majelis Penasihat Syariah.

Peran Majelis Penasihat Syariah hari ini sangat menantang, mengingat produk-produk keuangan syariah cukup rumit. Kondisi demikian memberi membawa konsekwensi khusus bagi para anggota MSP BNM untuk membuat keputusan yang tepat. Semakin rumit dan canggih suatu produk dan praktik keuangan syariah, maka peranan MPS BNM juga semakin kuat. Oleh karena itu, meskipun konsekwensi tgugas tersebut cukup berat, namun mereka tetap bersedia menangani dengan baik, karena didasarkan pada kesadaran bahwa merekalah yang bertanggungjawab terhadap kepatuhan penuh Syariah semua produk, praktik dan pelayanan keuangan syariah.

Berdasarkan keterangan dan perbandingan dengan negara Malaysia di atas, maka bagi Indonesia, anggota DPS sudah selayaknya memenuhi kualifikasi tertentu. DPS harus memahami ilmu keuangan dan perbankan meskipun para anggota DPS adalah ulama dan cendekiawan Islam, namun hal demikian sangat diperlukan, karena kebutuhan untuk memahami operasional perbankan dan ekonomi keuangan. Berdasarkan pemikiaran tersebut, perbankan syariah di Indonesia perlu menata ulang, perbaikan dan perubahan ke arah yang lebih baik, dengan antara lain mengangkat anggota DPS yang berkompeten dalam bidang mereka. Hal demikian sangat diperlukan guna mengoptimalkan peran mereka dalam pengembangan perbankan syariah di Indonesia. 
Strategi perbankan syariah di Indonesia yang mengangkat anggota DPS dari orang-orang yang sangat terkenal dalam organisasi masyarakat Islam, namun tidak kompeten dalam bidang perbankan dan keuangan syariah, merupakan langkah kurang tepat dan cukup banyak dijumpai. Mayoritas DPS tidak begitu memahami operasional perbankan syariah dan dalam mengawasinya pun tidak optimal. ${ }^{26}$ Kelemahan ini dimanfaatkan oleh manajemen perbankan syariah, mereka bebas untuk melakukan apapun, karena terjadi pengawasan sangat longgar. Tapi dalam jangka panjang hal demikian akan membahayakan gerakan ekonomi syariah, bukan hanya untuk perbankan syariah yang bersangkutan tetapi juga bagi pergerakan ekonomi dan perbankan syariah keseluruhan pada masa akan datang. Sehingga tidaklah mengherankan apabila ada pandangan bahwa bank syariah sama dengan bank konvensional. ${ }^{27}$

Pasal 35 Angka 1 Peraturan Bank Indonesia No. 03/11/PBI/2009 tentang Bank Umum Syariah, disebutkan bahwa tugas dan tanggung jawab DPS antara lain ialah untuk memberikan saran dan rekomendasi kepada Dewan Direksi dan mengawasi kegiatan-kegiatan bank sesuai dengan prinsip-prinsip Islam. Heri Sudarsono ${ }^{28}$ mengatakan bahwa fungsi DPS mengawasi operasional bank seharihari untuk melihat kesesuaian dengan prinsip-prinsip syariah, dan memeriksa serta membuat rekomendasi produk baru yang diperlukan dari bank tersebut. Namun demikian harus diakui, bahwa secara kelembagaan DPS sudah berperan melakukan pengawasan terhadap praktik kepatuhan syariah dalam perbankan syariah meskipun tidak optimal. Untuk itu setiap manajemen bank syariah perlu memformalkan peran dan keterlibatan DPS dalam memastikan manajemen risiko ketidakpatuhan terhadap prinsip syariah. DPS harus diberi ruang kantor di mana ada staf yang dapat memberikan pelayanan data keuangan, laporan keuangan, akad-akad, editor, proses pelaksanaan akad-akad, dan sebagainya.

Menurut hasil penelitian Bank Indonesia dengan kerjasama Ernst dan Young telah dibahas dalam satu seminar pada akhir tahun 2008 di Bank Indonesia. Salah satu masalah utama dalam pelaksanaan manajemen risiko dalam perbankan

${ }^{26}$ Wawancara dengan Thoha Abdurrahman, Ketua Majelis Ulama Indonesia di Yogyakarta 19 Juni 2014

${ }^{27}$ Muhammad Syakir Sula, Asuransi Syariah (Life and General), Jakarta: Gema Insani Press, 2004, hlm. 36.

${ }^{28}$ Heri Sudarsono, Bank dan Lembaga Kenangan Syariah Deskripsi dan Ilustrasi, Cetakan Keempat, Yogyakarta, Ekonisia, 2007, hlm. 41. 
syariah adalah peran DPS tidak optimal dan harus diperbaiki di masa depan..$^{29}$ Peran DPS jika tidak optimal terhadap praktik kepatuhan syariah mengakibatkan rusaknya citra dan kredibilitas bank syariah. Hal demikian, akan dapat mempengaruhi pandangan dan penilaian masyarakat, yang selanjutannya dapat mengurangi kepercayaan masyarakat terhadap perbankan syariah. ${ }^{30}$

Berdasarkan hasil penelitian oleh peneliti ditemukan kelemahan Dewan Pengawas Syariah yaitu: 1. Hingga kini tidak ada hukum khusus yang dipakai sebagai referensi bagi pengawasan khusus perbankan syariah; 2. DPS hanya digunakan sebagai objek pelengkap dalam sebuah lembaga perbankan syariah yang ada, struktur dapat diisi tanpa kriteria yang khusus berbasis keahlian; 3. Anggota DPS ditunjuk sebagai tokoh yang memiliki karisma dan popularitas di kalangan masyarakat, bukan karena keahlian pengetahuan mereka dalam bidang ekonomi dan perbankan syariah; 4. Anggota DPS dilantik dan diberikan gaji oleh bank syariah yang diawasinya, menjadikannya kurang bebas dan tidak objektif dalam pengawasan; 5. Anggota DPS adalah orang-orang yang sibuk dengan profesi utamanya, jadi ia tidak memiliki waktu yang cukup untuk menjalankan pengawasan. Pengawasan terhadap perbankan syariah hanya dilakukan sebagai pekerjaan sambilan; 6. DPS tidak ada kebebasan untuk bertindak tegas terhadap hasil pengawasannya. DPS hanya dapat memberikan peringatan tetapi tidak boleh menutup usaha perbankan yang bermasalah, maka pengawasan oleh DPS cenderung diabaikan; 7. Perbankan syariah adalah sangat rentan terhadap kesalahan yang dibagikan; 8. Kelemahan taraf sah bagi penilaian kepatuhan syariah oleh DPS karena ketidakefektifan dan ketidakefisienan mekanisme pengawasan syariah dalam perbankan syariah; 9. Terbatasnya kemahiran DPS dalam hal audit, akuntansi, ekonomi, dan hukum bisnis; 10. Tidak adanya mekanisme dan struktur kerja efektif DPS dalam menjalankan fungsi kontrol internal syariah di bank syariah; 11. Masih terdapat banyak kasus pelanggaran

\footnotetext{
${ }^{29}$ Agustianto, Meningkatkan Kualitas dan Kompetensi Dewan Pengawas Syariah, http://www.agustiantocentre.com/?p=830, diunduh tanggal 13 Februari 2015.

30 Shanin A. Shayan, CEO and Board Member of Barakat Foundation: "The biggest risk facing the global Financial System is not a fall in its earning power but most importantly a loss of faith and credibility on how it works". Dari penyataan tersebut, dapat dipahami bahwa menurutnya, risiko terbesar menghadapi sistem keuangan global bukanlah kesalahan tentang kemampuan mencipta keuntungan, tetapi yang lebih penting adalah kehilangan kepercayaan dan kredibilitas tentang bagaimana operasional kerjanya.
} 
prinsip-prinsip syariah yang dilakukan oleh institusi perbankan syariah, terutamanya bank-bank yang konversi ke syariah atau membuka Unit Usaha Syariah.

Berbagai hal yang demikian dapat mempengaruhi proses pengawasan dan menghasilkan pengawasan yang membingungkan, hanya sekadar formalitas. Hal tersebut tidak memberikan perlindungan kepada pengguna bank agar sesuai dengan prinsip-prinsip syariah. Selain itu, dalam bukunya Adrian Sutedi turut menyatakan, tidak sedikit DPS sangat jarang datang ke bank-bank syariah di mana DPS ditempatkan. Kalau pun mereka datang hanya untuk datang saja, mereka tidak memeriksa format dan kontrak editorial sesuai prinsip-prinsip syariah, bagaimana untuk menjalankan restrukturisasi bank, penjadwalan ulang, untuk penentuan margin, dan sebagainya. DPS kadang-kadang hanya sekali dalam sebulan, bahkan berbulan-bulan tidak datang langsung ke bank-bank syariah untuk dipantau. Jadi, tidak mengherankan bahwa ada banyak praktik perbankan syariah yang menyimpang dari prinsip-prinsip syariah. ${ }^{31}$

Semua transaksi di perbankan syariah harus dipantau secara optimal oleh DPS yang merupakan lanjutan dari DSN untuk meluruskan kesalahan yang terjadi dalam operasional perbankan syariah. Guna mendukung pengawasan yang baik maka di bank-bank syariah disediakan formulir aplikasi produk syariah yang benar-benar sesuai prinsip syariah yang telah ditetapkan oleh DSN. Menurut Thoha Abdurrahman kewajiban dan fungsi DPS tidak berjalan seperti yang seharusnya. Kadang-kadang ada DPS yang mengunjungi bank syariah hanya satu kali dalam sebulan, bahka ada juga yang hanya dapat dihubungi melalui telepon. Oleh karena aktivitas yang sangat sibuk di luar tugas sebagai DPS, mengakibatkan fungsi pengawasan syariah yang semestinya dilaksanakan menjadi tidak optimal. ${ }^{32}$

Memperhatikan hal demikian, dianjurkan jika ada Lembaga Keuangan Syariah (LKS) yang didirikan agar memilih DPS yang mengacu pada daftar anggota MUI yang memiliki kapasitas pemahaman dan komitmen yang baik terhadap produk-produk perbankan syariah. Memperhatikan realitas demikian,

31 Adrian Sutedi, Pasar Modal Syariah: Sarana Investasi Kenangan Berdasarkan Prinsip Syariah, Sinar Grafika, Jakarta, 2011, hlm.. 68.

32 Wawancara dengan Thoha Abdurrahman, Ketua Majelis Ulama Indonesia di Yogyakarta 19 Juni 2014. 
pada dasarnya, terdapat pihak-pihak yang turut prihatin dengan kualitas lembaga ekonomi syariah dan berkomitmen untuk memajukannya.

\section{Penutup}

Fungsi dan peran DPS dalam perbankan syariah, memiliki hubungan yang kuat dengan manajemen risiko perbankan syariah, yaitu risiko reputasi, yang pada gilirannya mempengaruhi risiko lain, seperti risiko likuiditas. Pelanggaran kepatuhan syariah yang dibiarkan oleh DPS jelas akan merusak citra dan kredibilitas perbankan syariah di mata publik, sehingga dapat mengurangi kepercayaan masyarakat terhadap perbankan syariah tersebut. Untuk alasan ini peran DPS pada perbankan syariah benar-benar harus dioptimalkan. Antaranya kualifikasi pengangkatan DPS harus diperketat melalui proses yang lebih selektif agar terpilih DPS yang mampu mengawasi dan mengawal operasional perbankan syariah sesuai prinsip-prinsip syariah.

\section{Daftar Pustaka}

\section{Buku}

Anshori, Abdul Ghofur, Hukum Perbankan Syariah (UU No. 21 Tahun 2008), Cetakan Pertama, Refika Aditama, Bandung, 2009.

Antonio, Muhammad Syafi'I, Bank Syariah: dari Teori ke Praktik, Gema Insani Press, Jakarta, 2010.

, Bank Syariah Wacana Ulama dan Cendekiawan, Cetakan Pertama, Tazkia Institute, Jakarta, 1999.

Chapra, M. Umer, dan Tariqullah Khan, Regulasi dan Pengawasan Bank Syariah, Bumi Aksara, Jakarta, 2008.

Dewi, Gemala, Aspek-Aspek Hukum dalam Perbankan dan Perasuransian Syariah di Indonesia, Kencana, Jakarta, 2004. , Hukum Perikatan Islam di Indonesia, Cetakan Ketiga, Kencana Prenada Group, Jakarta, 2007.

Hirsanuddin, Hukum Perbankan Syariah di Indonesia (Pembiayaan Bisnis dengan Prinsip Kemitraan), Cetakan Pertama, Genta Press, Yogyakarta, 2008.

Ismail, Perbankan Syariah, Cetakan Kedua, Kencana Prenada Media Group, Jakarta, 2013.

Karim, Adiwarman A., Bank Islam: Analisis Fiqih dan Kuangan, PT. Raja Grafindo Persada, Jakarta, 2011. 
Marzuki, Peter Mahmud, Penelitian Hukum, Prenada Group, Jakarta, 2014.

Mertokusumo, Sudikno, Penemuan Hukum, Liberty, Yogyakarta, 2004.

Muhamad, Bank Syariah Analisis Kekuatan, Peluang, Kelemahan dan Ancaman, Cetakan Pertama, Ekonosia, Yogyakarta, 2006.

Muhammad Ayub, Understanding Islamic Finance, diterjemahkan oleh Aditya Wisnu Pribadi, PT Gramedia Pustaka Utama, Jakarta, 2009.

Nazir, Habib, Muhammad Hassanuddin, Ensiklopedi Ekonomi dan Perbankan Syariah, Kaki Langit, Jakarta, 2004.

Ridwan, Muhammad, Konstruksi Bank Syariah Indonesia, Cetakan Pertama, Pustaka SM, Yogyakarta, 2007.

Sudarsono, Heri, Bank dan Lembaga Keuangan Syariah Deskripsi dan Ilustrasi, Cetakan Keempat, Ekonisia, Yogyakarta, 2007.

Sujamto, Beberapa Pengertian di Bidang Pengawasan, Cetakan Pertama, Ghalia Indonesia, Jakarta, 1986.

Sula, Muhammad Syakir, Asuransi Syariah (Life and General), Gema Insani Press, Jakarta, 2004.

Sutedi, Adrian, Pasar Modal Syariah: Sarana Investasi Keuangan Berdasarkan Prinsip Syariah, Sinar Grafika, Jakarta, 2011.

Situmorang, Victor M., Aspek Hukum Pengawasan Melekat, Rineka Cipta, Jakarta, 1994.

Sumitro, Warkum, Asas-asas Perbankan Islam dan Lembaga-lembaga Terkait, RajaGrafindo Persada, Jakarta, 2004.

Tahir, Hailani Muji \& Sanep Ahmad, Aplikasi Fiqh Muamalat dalam Sistem Keuangan Syariah, Pusat Penerbitan Universiti (UPENA), Shah Alam, 2009.

Tim Depdikbud, Kamus Besar Bahasa Indonesia, Ctk. Kedua, PT. Balai Pustaka, Jakarta, 1989.

\section{Jurnal}

Fitra Nelli, "Problematika Kiprah Dewan Pengawas Syariah (DPS) di Perbankan Syariah, Jurnal Al-Masharif, Vol. III, No. 1, Januari - Juni 2015.

Imam Abdul Hadi, "Kedudukan dan Wewenang Lembaga Fatwa (DSN MUI) pada Bank Syariah", Jurnal Economic, Vol. 1, No. 2, 2011.

Minarni, “Konsep Pengawasan, Kerangka Audit Syariah dan tata Kelola Lembaga Keuangan Syariah", Jurnal Ekonomi Islam La_Riba, Vol. VII, No. 1, Juli 2013.

Suryani, "Industri Perbankan Syariah dalam Cerminan Aspek Sharia Governance”, Jurnal Economica, Vol. V, Edisi 1, 2014.

\section{Peraturan Perundang-Undangan}

Kitab Undang-Undang Hukum Perdata (KUHPerdata). 
Undang-Undang Nomor 8 Tahun 1999 Tentang Perlindungan Konsumen (Lembaran Negara Republik Indonesia Tahun 1999 Nomor 42, Tambahan Lembaran Negara Republik Indonesia Nomor 3821).

Undang-Undang No. 10 Tahun 1998 tentang Perubahan Undang-Undang No. 7 Tahun 1992 tentang Perbankan (Lembaran Negara Republik Indonesia Tahun 1998 Nomor 182 , Tambahan Lembaran Negara Republik Indonesia Nomor 3790).

Undang-Undang No. 21 Tahun 2008 tentang Perbankan Syariah (Lembaran Negara Republik Indonesia Tahun 2008 Nomor 94, Tambahan Lembaran Negara Republik Indonesia Nomor 4867).

Undang-Undang No. 21 Tahun 2011 tentang Otoritas Jasa Keuangan (Lembaran Negara Republik Indonesia Tahun 2011 Nomor 111, Tambahan Lembaran Negara Republik Indonesia Nomor 5253).

Islamic Banking Act. (IBA) 1983 Malaysia, section 2.

Banking and Financial Institution Act. (BAFIA), 1989 Malaysia, section 124.

\section{Internet}

Agustianto, Meningkatkan Kualitas dan Kompetensi Dewan Pengawas Syariah, http:/ / www.agustiantocentre.com/?p=830, diunduh tanggal 13 Februari 2015 pukul 09.00

"Banking System in Malaysia: History of Development, Principles and Its Practice)", Jurnal Usuluddin, No. 14. December 2001. 